\title{
Editorial
}

\section{Gamification as a Field Landmark in Educational Research}

\author{
Lilia Raitskaya \\ Moscow State Institute of International Relations (MGIMO University) \\ Correspondence concerning this article should be addressed to Lilia Raitskaya, MGIMO University, $76 \mathrm{Pr}$. \\ Vernadskogo, Moscow, Russia, 119454.E-mail: raitskaya.l.k@inno.mgimo.ru \\ Elena Tikhonova \\ National Research University Higher School of Economics; \\ Peoples' Friendship University of Russia (RUDN University) \\ Correspondence concerning this article should be addressed to Elena Tikhonova, National Research \\ University Higher School of Economics, 26 Shabolovka, Moscow, Russian Federation, 119049. \\ E-mail: etikhonova@hse.ru
}

\begin{abstract}
In their editorial review, the JLE editors consider the concept of gamification, its spread in higher education research, and relevance at present. The authors analyse the current Scopus statistics to prove the prominence of the theme for researchers. The JLE scope can be further enriched via more studies on gamification in higher education and games in learning at large. The editorial may prompt the potential authors to proceed with more profound research in gamification learning techniques applicable to education.
\end{abstract}

Keywords: gamification; game; game-based learning; gamified app; student engagement; virtual environment; flow theory

\section{Gamification in Education}

Gamification first turned up as a buzzword and a hot topic in the 2000s. Starting from 2011, articles on gamification have increasingly been indexed in the Scopus and Web of Science (Web of Knowledge) databases. The continued focus on the topic spurs new studies, which are still on the rise (see Figure 1).

As some authors note 'it is difficult to trace the precise origin of the concept' of gamification (Kim, Song, Lockee \& Burton, 2018). Anyway, the term was coined some ten years ago. It turns out to be a complex phenomenon. For educational purposes, games have been designed and devised since the 1970s. As a learner's interest in game activities is transformed into engagement, games are potentially alluring and efficient. When academia comes round to thinking about appealing features of games, gamification for learning and game-based learning 'share common ground on the idea that game elements can make learning experiences more engaging' (Welbers et al., 2019). Findings from various studies fed the idea that 'the application of gamification could significantly influence the efficiency of human work and the enjoyment of executing it' (Stieglitz et al., 2017).

The popularity of games in educational contexts is also linked to the flow theory by M.Csikszentmihalui. Under the theory in question, the flow is a special mental state when a participant completely engages in the activity (game), 'applies full concentration of the activity, becomes unaware of the passage of time, does not feel selfconscious' (Kim, Song, Lockee \& Burton, 2018). Such deep and permanent engagement is vital for efficient learning.

Thus, gamification is a specially arranged system involving various activities aimed at learning and educational outcomes through game mechanisms. In the monograph 'Gamification in Learning and Education. Enjoy 
Learning Like Gambling' (Kim, Song, Lockee \& Burton, 2018), game is defined as 'an instructional approach that can be used to enhance the effectiveness of instruction on student learning'. Reiners and Wood (2015) defined gamification as 'a designed behavior shift through playful experiences'.

Games tend to attract attention of researchers in various areas, including business at large, psychology, medicine, social work, etc. But education in addition to computing still remain the main playgrounds and research areas. Games fit educational purposes and learning mechanisms perfectly well. 'The most recent studies have focused on applying gamification in the education sector to promote the learning process' (Hakak, 2019).

Despite the hype around the gamification, more studies are carried out to know in-depth the negative or ambivalent effects of games, especially over-engagement and addiction. The limits for gamification are also on the research agenda.

\section{Scopus Statistics of Gamification Research}

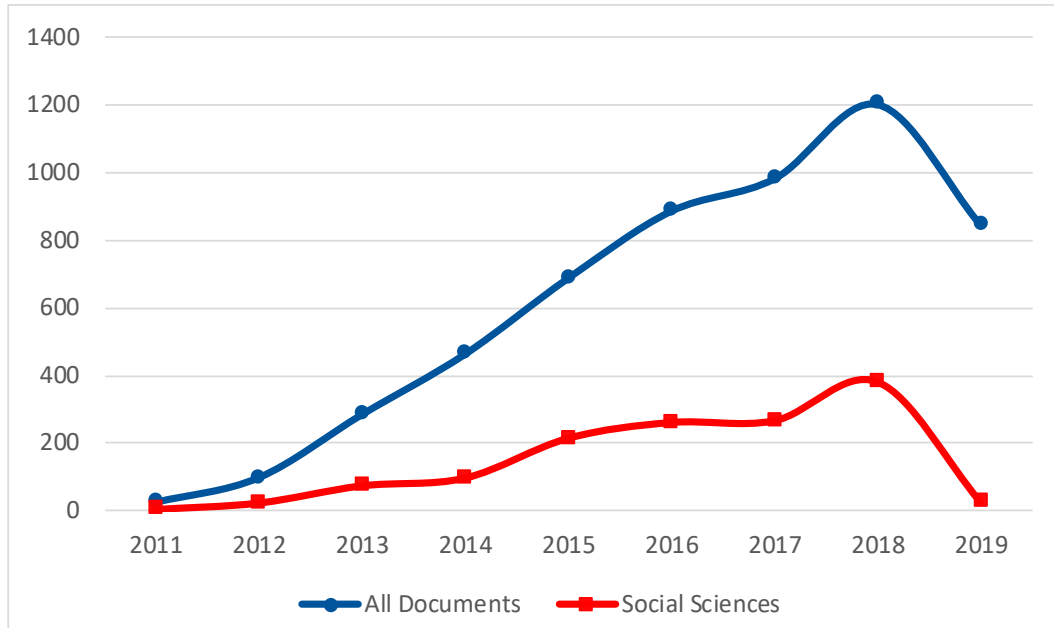

Source: Scopus Database as of September 28, 2019.

Figure 1. Scopus Indexed Documents on Gamification.

The total number of publications amounted to 5,517 (a search with 'gamification' in the field covering titles, abstracts and keywords in the Scopus database, accessed September 28, 2019). The breakdown of the documents proved their permanent rise. With only eight Scopus-indexed documents on gamification in 2011, the topic brought 199 publications in 2014, 481 papers in 2018 and 346 papers in 2019 (the 2019 data are incomplete so far). Of 5,517 documents, 5,322 are published in English, 94 are in Spanish. Social sciences accounted for 1,590 documents; computer sciences amounted to 3,912 papers; Arts \& Humanities worked out at 212 documents. The blue graph for all documents on gamification and the red graph for social sciences move in parallel (see Fig. 1). The data from the Web of Science database had 1,689 documents on gamification; the Science Direct brought 1,765 papers; SpringerLink had as many as 5,557 documents, including books and book series.

As for affiliations, the following universities and institutions had the highest counts of over 10 documents on gamification each (see Fig.2), with 18 documents from the Institute of Technology Carlow; 16 documents from the University of Hong Kong; 15 documents from Tampereen Yliopisto; 13 documents from Turun Yliopisto; 13 documents from Curtin University; 11 documents from Technische Universität Graz.

Of 1,590 documents on gamification limited to social sciences, articles accounted for 43.8 percent (697 documents); another 40.9 percent were marked as conference papers (650 documents). The remaining documents also cincluded 112 book chapters and 54 reviews (see Fig. 3).

As one can see from the Scopus statistics, there is a trend to call attention of the scientific community to the new research on gamification not only by articles, but by publications in proceedings volumes of conference reports. The 650 proceedings papers accounted for 40.9 percent of all the documents on gamification, limited to social sciences (see Fig. 3). They came out in 120 sources. The following conferences topped the list by the 


\section{LILIA RAITSKAYA, ELENA TIKHONOVA}

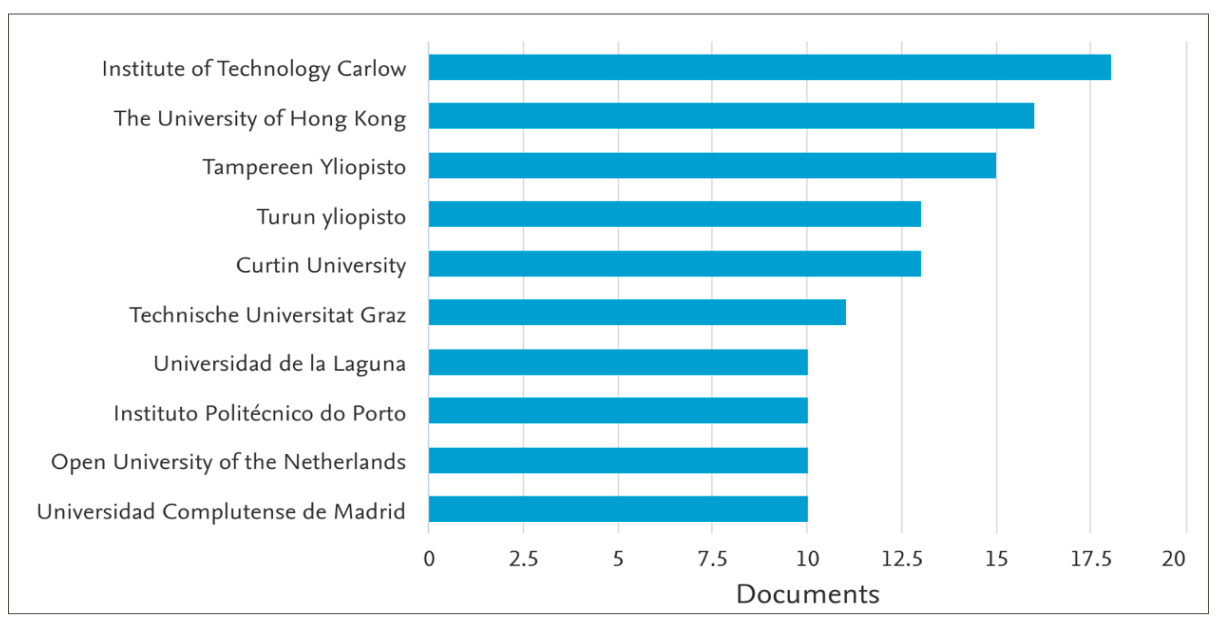

Source: Scopus Database as of September 28, 2019.

Figure 2. Scopus Indexed Gamification Research in Social Sciences: Affiliation Breakdown.

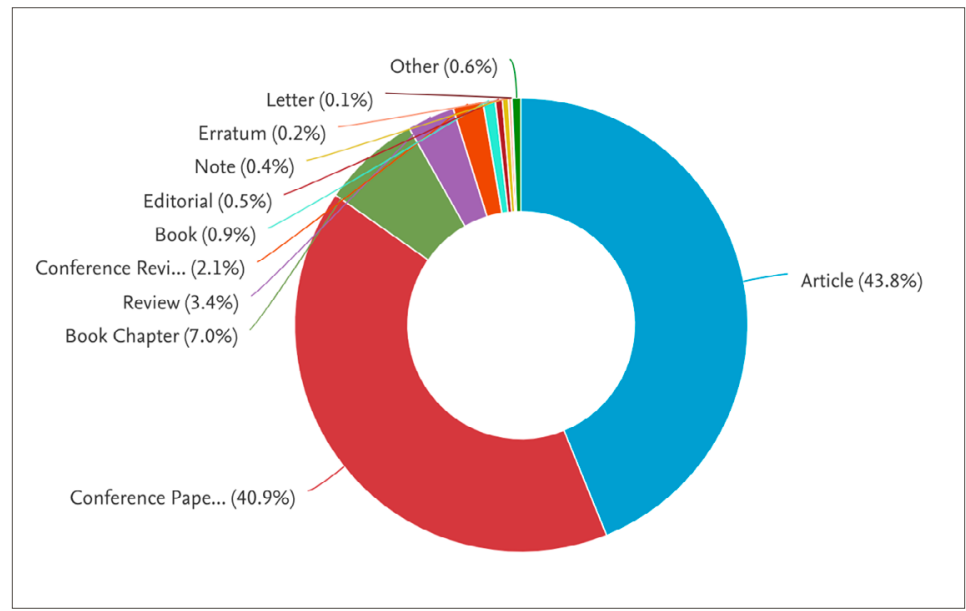

Source: Scopus Database as of September 28, 2019.

Figure 3. Scopus Indexed Gamification Research in Social Sciences: Types of Documents.

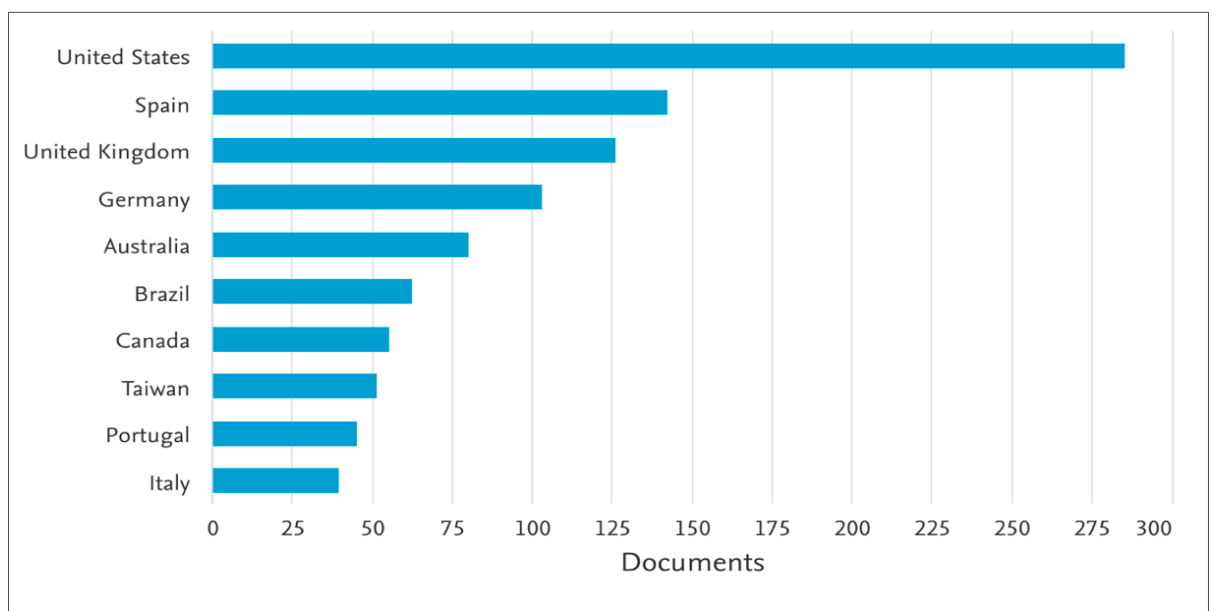

Source: Scopus Database as of September 28, 2019.

Figure 4. Scopus Indexed Gamification Research in Social Sciences: Leading Countries.

number of publications: the European Conference on Games Based Learning, IEEE Global Engineering Education Conference Educon, Annual Conference on Innovation and Technology in Computer Science Education Iticse, International Conference on Computer Supported Education Csedu, International Conference on Interactive 
Digital Media Icidm, IEEE International Conference on Teaching Assessment and Learning for Engineering Tale.

The document counts distributed between many countries and territories unevenly (see Fig. 4), with the US (854 documents), Germany (496 documents), the UK (446 documents), Spain (405 documents), Italy (241 documents) being the top runners.

\section{Gamification in Social Sciences and Educational Research: Top 100}

The top 100 cited articles on gamification (social sciences) include 64 documents related to education (mainly tertiary, including motivation (11), student engagement (7), language learning (2), professional education (8)) and 36 documents on gamification in other social spheres (tourism and other services (8), health protection and implications for health (5), psychology aspects (10), advertising (2)).

The most cited article on the list brought 552 citations. That is 'Gamifying learning experiences: Practical implications and outcomes' (Domínguez et al., 2013). The empirical article summed up the views of gamification in non-game contexts as of 2013. Its authors had designed a gamification plug-in for an e-learning platform for university students. The findings proved efficiency of the technique by better scores and higher motivation of the student participants (Domínguez et al., 2013).

\section{A Field Landmark}

In an attempt to determine the scope of research on gamification in education, viz. tertiary education, we focussed on the research in higher education contexts indexed in the Scopus database. To this end, we singled out all articles with 'gamification' as a keyword in the Scopus-indexed journals with educational scopes. We set the inclusion criteria for articles:

(1) the time span of nearly 10 years starting from the year when gamification research and documents were indexed in Scopus for the first time, viz. 2011 (January 1, 2011 - September 20, 2019) - 5,517 documents;

(2) all research with the 'gamification' in the search field, then limited to 'Social Sciences' (1,590 documents) and additional keywords from the list offered by the Scopus, including: students, education, e-learning, teaching, engineering education, game-based learning, higher education, education technology, learning environment, active learning, student engagement, blended learning, medical education, student motivation, pedagogy, distance education, flipped classroom, teaching and learning, educational games, problem based learning, gamification in education, learning outcome, technology enhanced learning, MOOCs, online learning.

The keywords were selected by each author to compare the results and settle the differences (only three keywords were under dispute, the latter was amicably settled to mutual satisfaction). All the keywords selected were integral to the higher education field. All in all, we found 257 articles of the kind.

At the final stage, each author studied the 257 articles to exclude those that cannot be attributed as research in higher education. Some educational studies of gamification that are not marked as 'tertiary/ higher education/ university-level' but essential for all stages of education remained on our final list. It included 138 documents ranging from 'Factors affecting students' self-efficacy in higher education' (Van Dinther, Dochy \& Segers, 2011) with the highest citation of 218 to 30 documents that had not been cited so far, including recently published.

Judging by our previous studies of the educational field at large, the theme in question is not as relevant as other major topics with hundreds and even thousands of documents. But it is under constant and detailed consideration. The research is centred around the following field segments:

- general gamification studies, practical implications and outcomes of gamification in education, students' perceptions of gamified or game-based learning (Domínguez et al., 2013), (Wiggins, 2016), (Erenli, 2013), (Markopoulos et al., 2015), (Brull \& Finlayson, 2016), (Rutledge et al., 2018), (Sánchez-Mena \& MartíParreño, 2017), (Mora, Riera, González \& Arnedo-Moreno, 2017), (Surendeleg, Murwa, Yun \& Kim, 2014), (Turan, Avinc, Kara \& Goktas, 2016), (Buckley, Doyle \& Doyle, 2017), (De Byl, 2013), (Laskowski \& Wojdyga, 2014), (Lin, Ganapathy \& Kaur, 2018), (Signori, De Guimarães, Severo \& Rotta, 2018);

- motivation in learning via games and game-based educational technologies (Hanus \& Fox, 2015), (Chen, 
Liu \& Hwang, 2016), (Perryer, Celestine, Scott-Ladd \& Leighton, 2106), (Zainuddin, 2018); (Ortiz-Colón, Jordán \& Agredai, 2018), (Gómez-Urquiza, 2019), (Rodríguez, Díaz, Gonzalez \& González-Miquel, 2018), (Chapman \& Rich, 2018), (Delello, 2018);

- $\quad$ student engagement in learning in game-based learning (Macfarlane \& Tomlinson, 2017), (Ibanez, Di-Serio \& Delgado-Kloos, 2014), (Caton \& Greenhill, 2014), (Hew, Huang, Chu \& Chiu, 2016), (Brigham, 2015), (Ding, Kim \& Orey, 2017), (Ding, Er \& Orey, 2018), (Coleman, 2018), (Sanmugam, 2015);

- effectiveness of games in education and learning (De-Marcos, Garcia-Lopez \& Garcia-Cabot, 2016), (Yildirim, 2017), (Hakulinen, Auvinen \& Korhonen, 2015), (Ab. Rahman, Ahmad \& Hashim, 2018), (Soboleva, Sokolova, Isupova \& Suvorova, 2017);

- games and individual learning styles (Buckley \& Doyle, 2017), (Barata, Gama, Jorge \& Gonçalves, 2014);

- gamification in language learning (Kétyi, 2016), (Gafni, Achituv \& Rachmani, 2017), (Sun \& Hsieh, 2018), (Fogarty, 2019).

\section{Conclusion}

With all that ten-year hype around gamification, it has become a field that still needs further scoping studies, but gamification exists and evolves as a research niche in educational research area. The research agenda is far from being straightforward, full of new green shoots. The present-day research goes beyond the early studies on the game potential for education and a limited range of game-based learning technologies. More studies come out to analyse the psychological mechanisms behind gaming for learning purposes and game-based learning; learning theories are explored to find more profound underpinnings for gamification.

JLE looks forward to new studies on the theme raised in our editorial review of gamification.

\section{References}

Ab. Rahman, R., Ahmad, S., \& Hashim, U. R. (2018). The effectiveness of gamification technique for higher education students engagement in Polytechnic Muadzam Shah Pahang, Malaysia. International Journal of Educational Technology in Higher Education, 15, 41. http://doi.org/10.1186/s41239-018-0123-0

Barata, G., Gama, S., Jorge, J., \& Gonçalves, D. (2014). Identifying student types in a gamified learning experience. International Journal of Game-Based Learning, 4(4), 19-36.http://doi.org/10.4018/ijgbl.2014100102

Brigham, T. J. (2015). An introduction to gamification: Adding game elements for engagement. Medical Reference Services Quarterly, 34(4), 471-480. http://doi.org/10.1080/02763869.2015.1082385

Brull, S., \& Finlayson, S. (2016). Importance of gamification in increasing learning. Journal of Continuing Education in Nursing, 47(8), 372-375. http://doi.org/10.3928/00220124-20160715-09

Buckley, P., \& Doyle, E. (2017). Individualising gamification: An investigation of the impact of learning styles and personality traits on the efficacy of gamification using a prediction market. Computers and Education, 106, 43-55. http://doi.org/10.1016/j.compedu.2016.11.009

Buckley, P., Doyle, E., \& Doyle, S. (2017). Game on. Student' perceptions of gamified learning. Educational Technology and Society, 20(3), 1-10. Retrieved from https://www.jstor.org/stable/26196115

Caton, H., \& Greenhill, D. (2014). Rewards and penalties: A gamification approach for increasing attendance and engagement in an undergraduate computing module. International Journal of Game-Based Learning, 4(3), 1-12. http://doi.org/10.4018/ijgbl.2014070101

Chapman, J. R., \& Rich, P. J. (2018). Does educational gamification improve students' motivation? If so, which game elements work best? Journal of Education for Business, 93(7), 314-321. http://doi.org/10.1080/0883232 3.2018.1490687

Chen, C. - H., Liu, G. -Z., \& Hwang, G. -J. (2016). Interaction between gaming and multistage guiding strategies on students' field trip mobile learning performance and motivation. British Journal of Educational Technology, 47(6), 1032-1050. http://doi.org/10.1111/bjet.12270

Coleman, J. D. (2018). Engaging undergraduate students in a co-curricular digital badging platform. Education and Information Technologies, 23(1), 211-224. http://doi.org/10.1007/s10639-017-9595-0

De Byl, P. (2013). Factors at play in tertiary curriculum gamification. International Journal of Game-Based 
Learning, 3(2), 1-21. http://doi.org/10.4018/ijgbl.2013040101

De-Marcos, L., Garcia-Lopez, E., \& Garcia-Cabot, A. (2016). On the effectiveness of game-like and social approaches in learning: Comparing educational gaming, gamification \& social networking. Computers and Education, 95, 99-113. http://doi.org/10.1016/j.compedu.2015.12.008

Delello, J. A., Hawley, H., McWhorter, R. R., Gipson, C. S., \& Deal, B. (2018). Gamifying education: Motivation and the implementation of digital badges for use in higher education. International Journal of Web-Based Learning and Teaching Technologies, 13(4), 17-33. http://doi.org/10.4018/IJWLTT.2018100102

Ding, L., Er, E., \& Orey, M. (2018). An exploratory study of student engagement in gamified online discussions. Computers and Education, 120, 213-226. http://doi.org/10.1016/j.compedu.2018.02.007

Ding, L., Kim, C., \& Orey, M. (2017). Studies of student engagement in gamified online discussions. Computers and Education, 115, 126-142. http://doi.org/10.1016/j.compedu.2017.06.016

Domínguez, A., Saenz-De-Navarrete, J., De-Marcos, L., Fernández-Sanz, L., Pagés, C., \& Martínez-Herráiz, J. -. (2013). Gamifying learning experiences: Practical implications and outcomes. Computers and Education, 63, 380-392. http://doi.org/10.1016/j.compedu.2012.12.020

Erenli, K. (2013). The impact of gamification: Recommending education scenarios. International Journal of Emerging Technologies in Learning, 8, 15-21. http://dx.doi.org/10.3991/ijet.v8iS1.2320

Fogarty, T. (2019). A description of gamification in teaching second language pharmacy technician students. Pharmacy Education, 19(1), 212-218.

Gafni, R., Achituv, D. B., \& Rachmani, G. J. (2017). Learning foreign languages using mobile applications. Journal of Information Technology Education: Research, 16(1), 301-317. http://doi.org/10.28945/3855

Gómez-Urquiza, J. L., Gómez-Salgado, J., Albendín-García, L., Correa-Rodríguez, M., González-Jiménez, E., \& Cañadas-De la Fuente, G. A. (2019). The impact on nursing students' opinions and motivation of using a "Nursing escape room" as a teaching game: A descriptive study. Nurse Education Today, 72, 73-76. http://doi. org/10.1016/j.nedt.2018.10.018

Hakak, S. et al. (2019). Cloud-assisted gamification for education and learning. Computers and Electrical Engineering, 74, 22-34. http://doi.org/10.1016/j.compeleceng.2019.01.002

Hakulinen, L., Auvinen, T., \& Korhonen, A. (2015). The effect of achievement badges on students' behavior: An empirical study in a university-level computer science course. International Journal of Emerging Technologies in Learning, 10(1), 18-29. http://doi.org/10.3991/ijet.v10i1.4221

Hanus, M. D., \& Fox, J. (2015). Assessing the effects of gamification in the classroom: A longitudinal study on intrinsic motivation, social comparison, satisfaction, effort, and academic performance. Computers and Education, 80, 152-161. http://doi.org/10.1016/j.compedu.2014.08.019

Hew, K. F., Huang, B., Chu, K. W. S., \& Chiu, D. K. W. (2016). Engaging asian students through game mechanics: Findings from two experiment studies. Computers and Education, 92-93, 221-236. http://doi.org/10.1016/j. compedu.2015.10.010

Ibanez, M. -., Di-Serio, A., \& Delgado-Kloos, C. (2014). Gamification for engaging computer science students in learning activities: A case study. IEEE Transactions on Learning Technologies, 7(3), 291-301. http://doi. org/10.1109/TLT.2014.2329293

Kétyi, A. (2016). From mobile language learning to gamification: An overlook of research results with business management students over a five-year period. Porta Linguarum, 45-59. Retrieved from https://www.ugr. es/ portalin/articulos/PL_monograph1_2016/art_4.pdf

Kim, S., Song, K., Lockee, B. \& Burton, J. (2018). Gamification in Learning and Education. Enjoy Learning Like Gaming. Switzerland: Springer. http://doi.org/10.1007/978-3-319-47283-6

Laskowski, M., \& Wojdyga, A. (2014). What can gamified university classroom teach us? Advanced Science Letters, 20(2), 402-405. http://doi.org/10.1166/asl.2014.5320

Lin, D. T. A., Ganapathy, M., \& Kaur, M. (2018). Kahoot! it: Gamification in higher education. Pertanika Journal of Social Sciences and Humanities, 26(1), 565-582.

Macfarlane, B., \& Tomlinson, M. (2017). Critiques of student engagement. Higher Education Policy, 30(1), 5-21. http://doi.org/10.1057/s41307-016-0027-3

Markopoulos, A. P., Fragkou, A., Kasidiaris, P. D., \& Davim, J. P. (2015). Gamification in engineering education and professional training. International Journal of Mechanical Engineering Education, 43(2), 118-131. http:// doi.org/10.1177/0306419015591324

Mora, A., Riera, D., González, C., \& Arnedo-Moreno, J. (2017). Gamification: A systematic review of design frameworks. Journal of Computing in Higher Education, 29(3), 516-548. http://doi.org/10.1007/s12528-0179150-4

Ortiz-Colón, A. M., Jordán, J., \& Agredai, M. (2018). Gamification in education: An overview on the state of the 
art. Educacao e Pesquisa, 44. http://doi.org/10.1590/S1678-4634201844173773

Perryer, C., Celestine, N. A., Scott-Ladd, B., \& Leighton, C. (2016). Enhancing workplace motivation through gamification: Transferrable lessons from pedagogy. International Journal of Management Education, 14(3), 327-335. http://doi.org/10.1016/j.ijme.2016.07.001

Reiners, T. \& Wood, L.C. (Eds.). (2015). Gamification in Education and Business. Switzerland: Springer. http://doi. org/ 10.1007/978-3-319-10208-5

Rodríguez, M., Díaz, I., Gonzalez, E. J., \& González-Miquel, M. (2018). Motivational active learning: An integrated approach to teaching and learning process control. Education for Chemical Engineers, 24, 7-12. http://doi. org/10.1016/j.ece.2018.06.003

Rutledge, C., Walsh, C. M., Swinger, N., Auerbach, M., Castro, D., Dewan, M., ... Chang, T. P. (2018). Gamification in action: Theoretical and practical considerations for medical educators. Academic Medicine, 93(7), 10141020. https://doi.org//10.1097/ACM.0000000000002183

Sánchez-Mena, A., \& Martí-Parreño, J. (2017). Drivers and barriers to adopting gamification: Teachers' perspectives. Electronic Journal of e-Learning, 15(5), 434-443.

Sanmugam, M., Zaid, N. M., Mohamed, H., Abdullah, Z., Aris, B., \& Suhadi, S. M. (2015). Gamification as an educational technology tool in engaging and motivating students; an analyses review. Advanced Science Letters, 21(10), 3337-3341. http://doi.org/10.1166/asl.2015.6489

Signori, G. G., De Guimarães, J. C. F., Severo, E. A., \& Rotta, C. (2018). Gamification as an innovative method in the processes of learning in higher education institutions. International Journal of Innovation and Learning, 24(2), 115-137. https://doi.org/10.1504/IJIL.2018.094066

Soboleva, E. V., Sokolova, A. N., Isupova, N. I., \& Suvorova, T. N. (2017). Use of training programs based on gaming platforms for improving the effectiveness of education. Novosibirsk State Pedagogical University Bulletin, 7(4), 7-25. https://doi.org/10.15293/2226-3365.1704.01

Stieglitz, S., Lattemann, C., Robra-Bissantz, S., Zarnekow, R., Brockmann, T. (Eds.). (2017). Gamification. Using Game Elements in Serious Contexts. Switzerland: Springer. https://doi.org/10.1007/978-3-319-45557-0

Sun, J. C., \& Hsieh, P. (2018). Application of a gamified interactive response system to enhance the intrinsic and extrinsic motivation, student engagement, and attention of english learners. Educational Technology and Society, 21(3), 104-116. Retrieved from https://www.jstor.org/stable/26458511?seq=1

Surendeleg, G., Murwa, V., Yun, H. -., \& Kim, Y. S. (2014). The role of gamification in education - a literature review. Contemporary Engineering Sciences, 7(29-32), 1609-1616. https://doi.org/10.12988/ces.2014.411217

Turan, Z., Avinc, Z., Kara, K., \& Goktas, Y. (2016). Gamification and education: Achievements, cognitive loads, and views of students. International Journal of Emerging Technologies in Learning, 11(7), 64-69. Retrieved from https://www.online-journals.org/index.php/i-jet/article/view/5455

Van Dinther, M., Dochy, F., \& Segers, M. (2011). Factors affecting students' self-efficacy in higher education. Educational Research Review, 6(2), 95-108. https://doi.org/10.1016/j.edurev.2010.10.003

Welbers, K., Konijn, E. A., Burgers, C., de Vaate, A. B., Eden, A., \& Brugman, B. C. (2019). Gamification as a tool for engaging student learning: A field experiment with a gamified app. E-Learning and Digital Media, 16(2), 92-109. https://doi.org/10.1177/2042753018818342

Wiggins, B. E. (2016). An overview and study on the use of games, simulations, and gamification in higher education. International Journal of Game-Based Learning, 6(1), 18-29. https://doi.org/10.4018/ IJGBL.2016010102

Yildirim, I. (2017). The effects of gamification-based teaching practices on student achievement and students' attitudes toward lessons. Internet and Higher Education, 33, 86-92. https://doi.org/10.1016/j. iheduc.2017.02.002

Zainuddin, Z. (2018). Students' learning performance and perceived motivation in gamified flipped-class instruction. Computers and Education, 126, 75-88. https://doi.org/10.1016/j.compedu.2018.07.003 